AJHSE Vol: 1 (2): 13-23, 2020

Article Ref. No.: AJHSE010203

Accepted Date: October 01, 2020

(C) 2020. CC License 4.0

www.ajhse.org
African Journal of Health, Safety and Environment

An official publication of the

Applied Environmental Bioscience and Public Health Research Group

University of Benin, Benin City, Nigeria

Open Access | Bi-annual | Peer-reviewed | International ISSN (Online): 2695-1819 | ISSN (Print): 2695-2386

\title{
THE PREVALENCE OF Chlamydia trachomatis AMONGST ASYMPTOMATIC PREGNANT WOMEN IN FOUR LOCAL GOVERNMENT AREAS OF DELTA STATE
}

\author{
${ }^{* 1}$ Bamikole, H. T., ${ }^{2}$ Idemudia, I. B., ${ }^{3}$ Imariagbe, E. E. and ${ }^{2}$ Ekhaise, F. O.
}

\author{
${ }^{* 1}$ Western Delta University, Oghara, Delta State, Nigeria \\ ${ }^{2}$ Department of Microbiology, University of Benin, P.M.B. 1154, Benin City, Edo state, Nigeria \\ ${ }^{3}$ Department of Environmental Management and Toxicology, University of Benin, Benin City, Edo State, Nigeria \\ *Corresponding Author Email: bamikolehelenrarebird@gmail.com Phone: +2348030581950
}

\begin{abstract}
7 he prevalence of Chlamydia trachomatis among asymptomatic pregnant women in four Local Government Areas (LGAs) in Delta State, Nigeria was investigated in this study. The four LGAs were Ethiope West,

L Sapele, Warri South and Warri North. A total of 200 pregnant women who visited the Primary Health Care Centres for antenatal care aged between 16 and 45 years were sampled across the four LGAs comprising 50 pregnant women from each of the LGAs between October 2017 and February 2018. The women were categorized into six age groups: 16 - 20, $21-25,26-30,31-35,36-40$ and $41-45$. Collected urine samples were examined in the laboratory for the presence of C. trachomatis using sedimentation and microscopy. Polymerase Chain Reaction (PCR) was used to identify the DNA of the isolated bacteria specimens. Results from the four LGAs showed that 93 pregnant women (46.5\%) tested positive for C. trachomatis. Prevalence was highest in the subjects from Warri North LGA (27/93) (29.03\%), while the least prevalent was the subjects from Warri South (19/93) (20.04\%). Women aged 26 30 had the highest prevalence (38/93) (40.86\%), while prevalence was least in women aged $41-45(3 / 93)(3.23 \%)$. There was no significant difference in number of infected pregnant women in the four Local Government Areas ( $p>0.05)$. Findings from this study are important, considering the growing concern of cases of infertility and death of newborn. Thus, there is a need for sexually active men and women to embark on routine check up to ascertain their health status.
\end{abstract}

Keywords: asymptomatic, chlamydia trachomatis, DNA, prevalence, PCR, urine sample

LICENSE: This article by African Journal of Health, Safety and Environment (AJHSE)is licensed and published under the Creative Commons Attribution License 4.0 International License, which permits unrestricted use, distribution, and reproduction in any medium, provided this article is duly cited.

COPYRIGHT: The Author(s) completely retain the copyright of this published article.

OPEN ACCESS: The Author(s) approves that this article remains permanently online in the open access (OA) mode.

QA: This Article is published in line with "COPE (Committee on Publication Ethics) and PIE (Publication Integrity \& Ethics)". 


\section{INTRODUCTION}

Chlamydia trachomatis is the etiological agent of the most common bacterial infection worldwide (Hoover et al., 2010). A peculiar feature of Chlamydia is that they are unable to synthesize their own energy (ATP) and are completely dependent on the host for energy (Hafner et al., 2008). Its virulence factor - the cell wall, has been characterized as Gram negative with a notable difference: it lacks muramic acid that is found in the walls of most other bacteria. This makes Chlamydia resistant to lactam antibiotics such as penicillin, because such antibiotics disrupt the typical cell wall which consist of muramic acid. Commonly unrecognized and often inadequately treated chlamydial infections can ascend the reproductive tract in women and cause pelvic inflammatory disease, which often results in the devastating consequences of infertility, ectopic pregnancy or chronic pelvic pain and it causes urethritis and chronic prostatitis in men (Sherk, 2003; Falk et al., 2011). Symptoms of infection in women include abdominal vaginal discharge, vaginal bleeding, bleeding after intercourse and dysuria. The urethra is the most common site of infection in males while urethra and cervix are commonly infected in females (Manavi, 2016).

Pregnant women are a special group at risk for $C$. trachomatis infection and may develop chlamydial clinical disease just like non-pregnant women, but they are also at increased risk for post-partum PID and subsequent infertility. Moreover, C. trachomatis infection during pregnancy may threaten the pregnancy and majority (up to 80\%) of pregnant and non-pregnant women, have no symptoms of the disease. Some of these infections may disappear spontaneously; others become overt cervicitis or urethritis or persist silently (Sheffield et al., 2005).

In Nigeria, studies have shown the prevalence of C. trachomatis ranged from $19.5 \%$ to $91.2 \%$ across different populations including patients attending gynaecological clinics (Jatau et al., 2009; Ebhohimhen et al., 2010; Osazuwa et al., 2013; Okoror et al., 2014). Ethiope West, Sapele, Warri North and South have a population of 203592, 142652, 137300 and 303417 respectively (Population Census, 2006). No information was provided on the sex distribution of the populations from these Local Government Areas. However, very little information has been documented on the prevalence of $C$. trachomatis in the four Local Government Areas of Delta State, Nigeria.

\section{MATERIALS AND METHODS}

\section{STUDY AREA}

The study was carried out in the four Local Government Areas of Delta State (Central and South Senatorial Districts): Ethiope West, Sapele, Warri North and South.

\section{ETHICAL CLEARANCE}

Approval for the study was obtained from the Delta State Hospitals Management Board with reference number CHW/ECC Vol/140.

\section{STUDY POPULATION}

A total of 200 pregnant women were sampled from the four Local Government Areas. Urine samples were collected from willing pregnant women aged between 16 and 45 years, who came for antenatal care at the Primary Health Care 
Centers with no symptom of Chlamydia infection in each of the Local Government Areas investigated. The women were categorized into six age groups: $16-20,21-25,26-30,31-35,36-40$ and $41-45$.

\section{SAMPLE COLLECTION}

The urine samples were collected (between October 2017 and February 2018) in sterile universal bottle and labeled accordingly with name, age and Local Government Area and were preserved inside cooler box plus ice pack and transported immediately to the Benson Idahosa University Research Central Laboratory, Benin City for analysis.

\section{SEDIMENTATION, MICROSCOPY AND DNA EXTRACTION}

Urine samples measuring $1400 \mu \mathrm{l}$ were concentrated and pipetted into microfuge tube and centrifuged at 10,000 rpm/1 min. The supernatant was gently discarded and then tapped to collect about $200 \mu \mathrm{l}$ of the concentrated urine sample. Concentrated urine samples of $200 \mu \mathrm{l}$ were pipetted into bash bead and $750 \mu \mathrm{l}$ of lyses solution was added and vortexed for $5 \mathrm{~min}$ and the samples were centrifuged at 10,000 rpm/1 min. The supernatant of $400 \mu 1$ was transferred into zymospin IV spin filter (orange top) in a collection tubes and spin IV spin filter (orange top) in a collection tubes and centrifuged at 7,000 rpm/1 min and the base of the zymo-spin IV were snapped prior to use. Genomic lyses buffer of $1200 \mu \mathrm{l}$ was added to the filtration in collection tube in the later step above, $800 \mu \mathrm{l}$ was transferred into zymo-spin IIc column in collection tube and centrifuged at $10,000 \mathrm{rpm} / 1 \mathrm{~min}$, then the flow through were discarded and the later step was repeated. The extracts from the urine sample were examined under a microscope for presence of bacteria.

This process was followed by DNA extraction which was required for species-specific identification using PCR. The DNA extraction was according to the methods described by Peuchant et al. (2015). DNA pre-wash buffer of $200 \mu 1$ was added to zymo-spin IIc column in a new collection tube and centrifuged at 10,000 rpm/min and $500 \mu \mathrm{lg}$-DNA buffers was added to spin IIc column and centrifuge at 10,000 rpm/1 min. The zymo-spin IIc column was transferred into $1.5 \mu 1$ microfuge tube and $100 \mu 1$ DNA elution buffer was added directly to the zymo-spin IIc column and centrifuged at 10,000 rpm/30 sec and then stored at $4^{\circ} \mathrm{C}$ prior to PCR Peuchant et al. (2015).

\section{SPECIES-SPECIFIC IDENTIFICATION USING PCR}

Species-specific identification using PCR was done according to the procedures described by Keane et al. (2007). The extracted bacterial genomic DNA was amplified using Chlamydia trachomatis specific primers: KL1-F (5'TCCGGAGCGAGTTACGAAGA-3') and KL2-R (5'-AATCAATGCCCGGGATTGGT-3'). PCR procedure was carried out in a final reaction mixture of $25 \mu \mathrm{L}$ in $200 \mu \mathrm{L}$ PCR tube. The mixture in the PCR tubes was tapped gently and spun briefly at 10,000 rpm. The PCR tubes with all the components were thereafter transferred to Peltier-Based Thermal cycler (MG96+/Y, Hangzhou, Zhejiang, China). After amplification, the expected PCR products were verified by gel electrophoresis containing ethidium bromide $0.5 \mathrm{mg} / \mathrm{L}$ for $1 \mathrm{~h}$ at $100 \mathrm{~V}$ on $0.5 \mathrm{x}$ TAE buffer $(40 \mathrm{mmol} / 1$ Tris-HCl, 20mmol/l Na-acetate, $1 \mathrm{mmol} / \mathrm{L}$ ethylene diamine tetracetic acid, $\mathrm{pH} 8.5$ ) and visualized under a UV transilluminator (Vilber Lourmat EBOX VX5, France). The extracted DNA of C. trachomatis in the urine samples was denatured at $94^{\circ} \mathrm{C}$ (for 3 minutes). Annealing was done at $53^{\circ} \mathrm{C}$ (for 50 seconds) while extension of the PCR was carried out at $72^{\circ} \mathrm{C}$ (for 3 minutes) in 35 cycles. 


\section{STATISTICAL ANALYSIS}

Results were analyzed using percentage, prevalence and graphical representations. One sample t-test was used to determine significant difference in the number of infected samples amongst the Local Government Areas investigated using SPSS Version 20 (Ogbeibu, 2005).

\section{RESULTS}

A total of 93 samples out of the 200 samples were found to contain genetic sequence related to that of Chlamydia trachomatis-specific primer accounting for $46.5 \%$ of the total sample collected.

Out of the $46.5 \%$ positive cases (Fig. 1), samples collected from Warri North LGA had the highest prevalence of $29.03 \%$ (27/93), while Warri South LGA had the least prevalence of 20.04\% (19/93). Others were Sapele LGA with a prevalence of 26.88\% (25/93) and Ethiope West 23.66\% (22/93).

Highest prevalence of $C$. trachomatis was observed within the age group of 26 - 30 with a percentage occurrence of $40.86 \%$ (38/93), while 41 - 45 had the least percentage occurrence of 3.23\% (3/93). Ages 16 - 20,21 25,31 - 35 and 36 - 40 had prevalence of $4.30 \%, 7.35 \%, 18.28 \%$ and $25.81 \%$ respectively. The study also revealed that Warri North LGA aside having the highest prevalence also had 51.85\% (14/27) of positive cases within the ages of 26 - 30. The study also revealed that women of ages 41- 45 in Ethiope West and Warri North LGAs had no positive cases of C. trachomatis as seen in Fig. 2.

There was no significant difference in infection ( $p>0.05)$ amongst the positive samples of the women from the four local government areas as seen in Table 1.

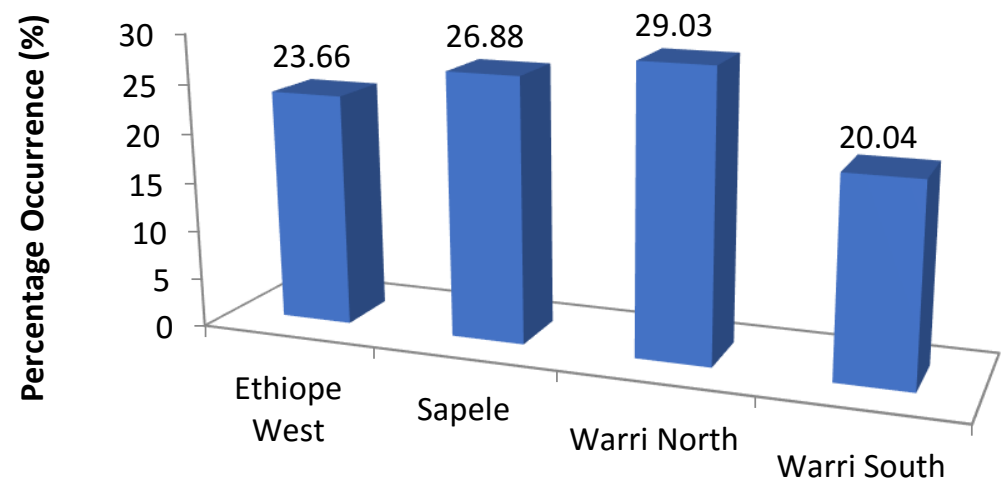

\section{Local Government Areas}

Figure 1: Percentage occurrence of Chlamydia trachomatis in the Local Government Areas 


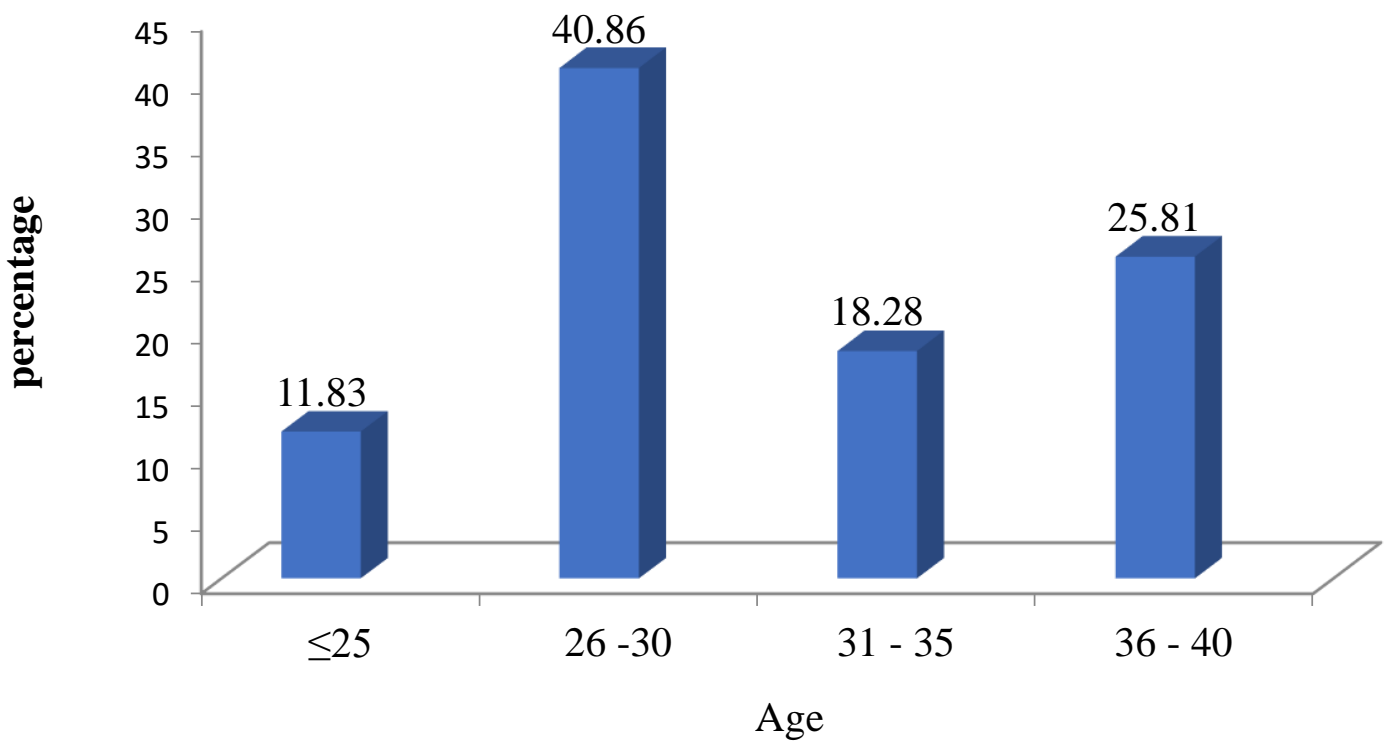

Figure 2: Percentage of positive cases within the age groups across the Local Government Areas

Table 1: One Sample T-Test Comparing the Positive Cases from the Four Local Government Areas

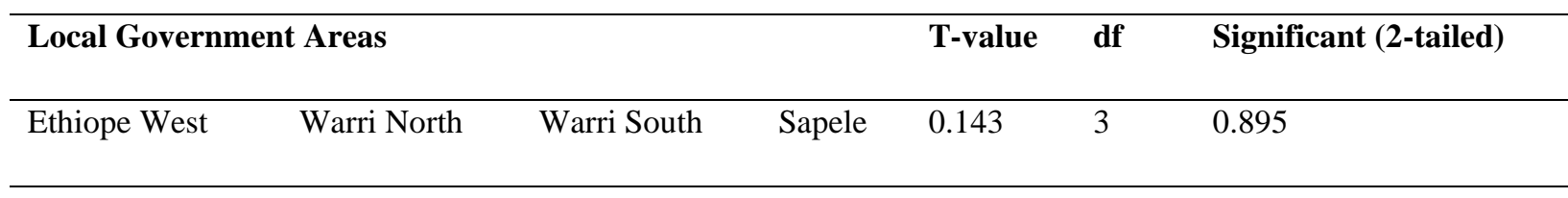

\section{DISCUSSION}

Chlamydia trachomatis infection is generally considered as a silent infection and hence, known as an asymptomatic infection. It is usually found in latent infection occurring unnoticed and remain endemic in the population for a long time (Mawak et al., 2011). This study consisted of 200 pregnant women attending antenatal care clinics in Ethiope West, Sapele, Warri North and Warri South Local Government Areas of Delta State, Nigeria.

This study reports a prevalence of $46.5 \%$ (93/200) in the population sampled across four Local Government Areas of Delta State, Nigeria. This result is lower than a prevalence of over 51\% reported by Okoro et al. (2007) in South East and 51.6\% reported by Mawak et al. (2011) in Jos, Plateau State, Nigeria. A lower prevalence of 41\% (Okoror et al., 2014) in South-western Nigeria; $38.3 \%$ by Tukur et al. (2006) in Northern Nigeria and $13.3 \%$ by Isibor et al. (2005) in Benin City has been reported. Bakhtiari, and Firoozjahi, (2007) reported 11.6\% in Babol, Iran. da Silveira et al. (2017) reported 12.3\% in Brazil. These reports are however, in contrast to the observation from some other countries such as United States of America where approximately 4 million cases of Chlamydial infection are reported annually with an overall prevalence of 5\% (CDC, 2009) and in Ethiopia 5.9\% (CDC, 2009). Prevalence of Chlamydia-asymptomatic women in Europe ranged from 1.7 - 17\% depending on the setting, context and country (Wilson et al., 2002). The high prevalence in this study is in agreement with earlier reports of Sturm-Ramirez et al. (2000) and Okoror et al. (2014), where it was reported that prevalence of Chlamydia trachomatis infection will 
continue to grow in African population. Possible explanation for lower prevalence in Warri South could be attributed to several factors such as the lower sample size enrolled in the study and the detection technique employed (Nwankwo and Magaji, 2014). Mawak et al. (2011), in their report, attributed high difference in prevalence to be as a result of reduced sexual risk-behaviour, increased awareness on Chlamydial infection and other sexually transmitted diseases, easy access to laboratory, diagnoses and treatment among others in developed countries of which the reverse is the case in developing countries.

Comparing the results between the local governments, showed that of the $46.5 \%$ positive cases, samples collected from Warri North LGA had the highest prevalence of 29.03\% (29/93) while Warri South LGA had the least prevalence of $20.04 \%$ (19/93). Others were Sapele LGA with a prevalence of 26.88\% (25/93) and Ethiope West $23.66 \%$ (22/93). Although the differences in prevalence between the local government areas are not significant, it calls for immediate attention as other risk factors such as inadequate screening, abortion, multiple sexual partners, traditional rites, use of public toilet and ignorance or lack of awareness of Chlamydia trachomatis by the women could be present.

Authors on the prevalence of Chlamydia trachomatis infection have always pinpointed age to be one of its major risk factors. Although the results of the positive cases from the four Local Government Areas were not significantly different, results showed that most of the positive cases where from women aged between $26-30$ across the four Local Government Areas, which is the most active age group for sex in women and thus forms the high-risk group (Baud et al., 2008; Ikeme et al., 2011).

The different age stratification used in this study showed that women within the age 26 - 30 had the highest prevalence of Chlamydia trachomatis in the four LGAs with a percentage occurrence of $40.86 \%$ (38/93), while 4 451 had the least percentage occurrence of 3.23\% (3/93). Ages 16-20, 21-25, 31-35, 36-40 had prevalence of 4.30\%, $7.35 \%, 18.28 \%$ and $25.81 \%$ respectively. This report is in agreement with that of Marcone et al. (2012) and Nwankwo and Magaji, (2014), who in their separate works reported that women within the ages of 25 - 29, had the highest prevalence of Chlamydia trachomatis infection.

The observation made in the study of no significant difference in age group prevalence is in agreement with the findings of Mawak et al. (2011) and Oloyede et al. (2009). Nwankwo and Magaji (2014) described these age groups of to be of high sexual activity and this may be responsible for high prevalence observed. The decreased susceptibility to infection with age (41-45) has been attributed to changes in epithelial cells and linings of the female reproductive system, which may result in a decreased rate of infection in elderly as observed (Bakhtiari and Firoozjahi, 2007) in this report which showed that 3.32\% in pregnant women aged 41-45. Partial immunity in this elderly can also prevent re-infection (Bachmann et al., 2003). The effect of age may also be attributed to residual confounding due to non-measured sexual characteristics such as frequency of sexual intercourse per partner and the duration of intercourse (Van Duynhoven et al., 1997). In agreement with these several reports, The CDC has recommended screening for all women at the first antenatal visit with rescreening in the third trimester in women aged $\leq 25$ years (CDC, 2010).

The high prevalence reported in this study is also attributed to the method used for the identification of the bacteria which is polymerase chain reaction (PCR) through nucleic acid amplification testing. This is in agreement 
with the report of Bakhtiari and Firoozjahi, (2007) that attributed the low prevalence in their study, was due to the serology-based method testing method used. Nucleic acid amplified test in this study, probably shows the true prevalence of Chlamydia trachomatis.

\section{CONCLUSION}

Chlamydia trachomatis infection is prevalent in the studied area and should be considered a silent epidemic that needs urgent attention. Since there is no available protective vaccine against Chlamydial infections and untreated infection can cause irreversible damage to female reproductive system including infertility and death of the neonates, there is a need for the government to develop and implement Chlamydial Control Strategies (CCS). With a $46.5 \%$ prevalence of $C$. trachomatis asymptomatic infection in pregnant women in four LGAs, Chlamydia screening, awareness campaigns of women of reproductive age and monitoring activities should be initiated, implemented and supported by the Delta State Government, Ministry of Health and other governmental and nongovernmental bodies. 


\section{REFERENCES}

Bachmann, L.H., Pigott, D., Desmond, R., Jones, M., Lumpkins, J., Gala, P., Terndrup, T. and Hook, E.W. (2003). Prevalence and factors associated with gonorrhea and chlamydial infection in at-risk females presenting to an urban emergency department. Sexually Transmitted Diseases 30(4):335-339.

Bakhtiari, A. and Firoozjahi, A. (2007). Chlamydia trachomatis infection in women attending health centres in Babol: Prevalence and risk factors. Eastern Mediterranean Health Journal 13(5):1124-1132.

Baud, D., Jaton, K., Bertelli, C., Kulling, J. and Greub, G. (2008) Low prevalence of Chlamydia trachomatis infection in asymptomatic young Swiss men. BMC Infectious Diseases, 8: 45.

Centres for Disease Control and Prevention, Workowski, K.A. and Berman, S.M. (2010). Sexually transmitted diseases treatment guidelines. MMWR-Recommendation Report 59(12):1-110.

Centres for Disease Control and Prevention (CDC). (2009). Chlamydia screening among sexually active young female enrollees of health plans-United States 2000-2007. MMWR-Recommendation Representation: Morbidity and Mortality Weekly Report 58:362-365.

da Silveira, M.F., Sclowitz, I.K.T., Entiauspe, L.G., Mesenburg, M.A., Stauffert, D., de Oliveira Bicca, G.L., Pieniz, C. and Manta, A.B. (2017). Chlamydia trachomatis infection in young pregnant women in Southern Brazil: A cross-sectional study. Reports in Public Health 33(1):1-9.

Ebhohimhen, E.O., Adejumo, B.I.G., Ibeh, I.N., Ebhohimhen, B.O., Abdulkadir, U.I., Dimkpa, U., Oke, O.M., Emmanuel, A.M., Fwogos, I.J., Abdulkadir, R.L. and Uchuno, A.G. (2017). Prevalence of asymptomatic Chlamydia trachomatis infection among HIV positive patients in Warri metropolis, Delta State, Nigeria. Nigerian Biomedical Science Journal

Falk, L., Fredlund, H. and Jensen, J.S. (2005). Signs and symptoms of urethritis and cervicitis among women with or without Mycoplasma genitalium or Chlamydia trichomatis infection. Sexually Transmitted Infection 81:7178.

Hafner, L., Beagley, K. and Timms, P. (2008). Chlamydia trichomatis infection: host immune responses and potential vaccines. Mucosal Immunology 1:116-130.

Hoover, K.W., Tao, G. and Kent C. K. (2010). Trends in the diagnosis and treatment of ectopic pregnancy in United States. Clinical Obstetrics and Gynaecology 115:495-502.

Ikeme, A.C., Ezegwui, H.U., Ikeako, L.C., Agbata, I. and Agbata, E. (2011). Seroprevalence of Chlamydia trachomatis in Enugu, Nigeria. Nigerian Journal of Clinical Practice, 14 (2): 176-180.

Jatau, E.D., Ella, E.E. and Ekwudu, O. (2009). Prevalence of Chlamydia trachomatis infections among patients attending gynaecological clinics in Zaria, Northern Nigeria. Biological and Environmental Sciences Journal for the Tropics 6(4): 131-133.

Keane, F.E., Bendall, R., Saulsbury, N. and Haddon, L.A. (2007). Comparison of self-taken vulvovaginal and cervical samples for the diagnosis of Chlamydia trachomatis infection by Polymerase Chain Reaction. International Journal of Sexually Transmitted Diseases 18:98-100. 
Manavi, K. (2006). A review on infection with Chlamydia trachomatis: Best practice and research. Clinical Obstetrics and Gynaecology 20:941-951.

Marcone, V., Recine, N., Gallinelli, C., Nicosia, R., Lichtner, M., Degener, A.M., Chiarini, F., Calzolari, E. and Vullo, V. (2012). Epidemiology of Chlamydia trachomatis endocervical infection in a previously unscreened population in Rome, Italy: 2000 to 2009. Euro Surveillance 17(25):1-8.

Mawak, J.D., Dashe, N., Agabi Y.A. and Panshak B.W. (2011). Prevalence of genital Chlamydia trachomatis Infection among gynaecologic clinic attendees in Jos, Nigeria. Shiraz E-Medical Journal 12(2):100-106.

Nwankwo, E.O. and Magaji, N.S. (2014). Prevalence of Chlamydia trachomatis infection among patients attending infertility and sexually transmitted diseases clinic (STD) in Kano, North Western Nigeria. African Health Sciences 14(3):672-678.

Ogbeibu, A.E (2005). Biostatistics: A Practical Approach to Research and Data Handling. Mindex Publishing Company Limited, Benin City. 264pp.

Okoro, L.E., Agbonlahor, D.E., Esumeh, F.I, and Umolu, P.I. (2007). Prevalence of Chlamydia in patients attending gynaecological clinics in South Eastern Nigeria. African Health Sciences 7(1):18-24.

Okoror, L.E., Otoickian, C., Eniolorunda, T. and Omoniyi, F.D. (2014). Prevalence and risk of Chlamydia trachomatis in symptomatic patients attending clinics in South West Nigeria. Archives of Clinical Microbiology 5(5):111.

Oloyede, O.A.O., Fakoya, T.A., Oloyede, A.A. and Alayom, A.M. (2009). Prevalence and awareness about chamydial infection in women undergoing infertility evaluation in Lagos, Nigeria. International Journal of Health Research 2(2):157-163.

Osazuwa, F., Aiguobarueghian, O.I., Alekwe, L., Imade, P.E., Ibadin, K.O. and Aberare, L.O. (2013). The prevalence of Chlamydia trachomatis infection among infertile males and its association with abnormal semen characteristics in Delta State, Nigeria. Tanzania Journal of Health Research 15(2): 1-5.

Peuchant, O., Leroy, C., Desveaux, C., Paris, A., Asselineau, J., Maldonado, C., Chene, G., Dallay, D., De Barbeyrac, C. and Bebear, C. (2015). Screening for Chlamydia trichomatis, Neisserria gonorrhoeae and Mycoplasma genitalium: Should it be integrated into routine pregnancy care in French young pregnant women? Diagnosis Microbiology Infectious Disease 82:14-19.

Population Census (2006). Delta State Household and Housing Survey. Delta State Government.

Sheffield, J.S., Andrews, W.W., Klebanoff, M.A., Macpherson, C., Carey, J.C. and Ernest, J.M. (2005). Spontaneous resolution of asymptomatic Chlamydia trachomatis in pregnancy. Obstetrics and Gynecology 105(3):557562 .

Sherk, V. (2003). Comparative analysis of azithromycin and ciprofloxacin in the treatment of chronic prostatitis caused by Chlamydia trichomatis. International Journal of Antimicrobial Agents 20:457-462.

Sturm-Ramirez, K., Brumblay, H., Diop, K., 'Ye-ndiaye, A.G., Sankale, J-L., Ithior, I., N'doye, I., Hsieh, C-C., Mboup, S., and Kanki, P.J. (2000). Molecular Epidemiology of genital Chlamydia trachomatis Infection in high-risk women in Senegal, West Africa. Journal of Clinical Microbiology 38(1): 138-145. 
Tukur, J., Shittu, S.O. and Abdul, A.M. (2006). A case control study of active genital Chlamydia trachomatis infection among patients with tubal infertility in northern Nigeria. Tropical Doctors 36(1):14-26.

Van Duynhoven, Y.T., van de Laar, M.J., Schop, W.A., Mouton, J.W., van der Meijden, W.I. and Sprenger, M.J. (1997). Different demographic and sexual correlates for chlamydial infection and gonorrhoea in Rotterdam. International Journal of Epidemiology 26(6):1373-1385.

Wilson, J.S., Honey, E., Templeton, A., Paavonen, J. and Mgrdh, P.A. (2002). Stary A and Stray-Pedersen B for the EU Biomed Concerted Action Group. A systematic review of the prevalence of Chlamydia trachomatis among European women. Human Reproduction Update 8(4):385-394. 